\title{
Relationship between soil contents and plasma levels of selenium, chromium and manganese in healthy adult Nigerians
}

\author{
Kolawole Sunday E. ${ }^{1 *}$ and Obueh Henrietta $\mathrm{O}^{2}$ \\ ${ }^{1}$ National Open University of Nigeria, Benin Study Centre, Benin City, Nigeria. \\ ${ }^{2}$ Department of Biology, College of Education, P.M.B 1144, Benin City, Nigeria.
}

Accepted 8 August, 2013

\begin{abstract}
The soil contents of trace elements selenium, chromium and manganese were measured to determine their impact on the plasma levels of $\mathbf{1 6 0}$ healthy adult Nigerians in five different experimental locations in Cross River and Akwa Ibom States, South - South Nigeria. The mean ( $\pm S D$ ) soil selenium, chromium and manganese concentrations were $2.86 \pm 3.97,15.93 \pm 3.35$ and $90.33 \pm 42.65 \mathrm{mg} / \mathrm{kg}$, respectively. Manganese soil concentration was the highest and selenium soil concentration was the lowest in all the locations. The mean ( $\pm S D$ ) plasma selenium, chromium and manganese concentrations were 0.006 , $0.111 \pm 0.031$ and $0.028 \pm 0.024 \mathrm{mg} / 1$, respectively. There were no significant differences between the concentrations of the trace elements in the soil and the plasma levels as determined by t-test. Plasma levels of chromium and manganese according to the study were adequate but that of selenium was low.
\end{abstract}

Key words: Healthy adult Nigerians, trace elements, plasma level, soil content.

\section{INTRODUCTION}

Trace elements like selenium, chromium and manganese are inorganic nutrients that originate in the earth and cannot be made in the body. They play important roles in the various bodily functions and are necessary to sustain life and maintain optimal health, and thus, are essential nutrients (Tourmma, 1995). Most of the minerals in the human diet come directly from plants and water, or indirectly from animal foods. However, the mineral content of water and plant foods varies according to different geographical zones because of variations in the mineral content of soil from region to region (Combs, 2001). For many people with access to an adequate energy intake, an extensive freedom of choice exists in selection of food. However, the existence of widespread poverty in Nigeria precludes the opportunity to consume adequate energy let alone a diet balanced with micronutrients. Micronutrient deficiency is caused by inadequate access to micronutrient-rich food, high burden of infection and parasites, and detrimental feeding and dietary practices (Tuormaa, 1995). Micronutrients deficiency adversely affects the health and function of individuals and the economic and social development of communities and nations. Micronutrients usually function as essential cofactors in the numerous enzymes catalyzed reactions. Serious disease conditions due to the impairment of metabolic functions can occur in the absence of micronutrients. For example, obesity and dietrelated chronic diseases such as diabetes and cardiovascular diseases have been reported to be on the increase in many developing countries affected by rapid industrialization and urbanization (Eckhardt, 2006). Selenium may have an anti-carcinogenic effect. Observational studies indicate that death from cancer, including lung, colorectal, and prostrate cancers is lower among 
people with higher blood levels or intake of selenium (Combs et al., 1997).

The role of selenium for the proper functioning of the thyroid gland has also been documented. Selenium status has been suggested to be a significant predictor of survival for persons infected with HIV (Fairweather-Tait, 1997). Chromium has been reported to play a role in a number of metabolic systems. The role of chromium in insulin function, diabetes mellitus, metabolic syndrome, polycystic ovarian syndrome and depression has been revealed by current research (Vincent, 2000). Manganese, a nutritionally essential antioxidant nutrient is reported to play an important role in the breakdown of amino acids and the production of energy. Manganese is a component of manganese superoxide dismutase $(\mathrm{MnSoD})$. The role of this antioxidant enzyme in the dismutation of superoxide radicals has also been documented. There are also reports associating low dietary levels of manganese with abnormal bone development and abnormal wound healing in a number of animal species (Keen and Zindenberg - Cherr, 1996).

Many minerals and trace elements are inefficiently and variably absorbed from the diet. Determination of adequacy of dietary intake is complicated by the numerous interactions which exist among trace elements among these and other dietary components and variations in the bio-availability of trace elements in different foods. Interactions of trace metals are potent and could be either positive or negative (Tuormaa, 1995). For the healthy population, consumption of a nutritionally adequate diet balanced with regard to major nutrients generally is relied upon to provide an adequate and safe intake of trace element. Selenium, chromium and manganese unlike macronutrients are ingested in very small amounts (microgrammes and milligrams per day). Despite their relative paucity in the diet and body, they perform important roles in regulating whole body metabolism. This study was designed to investigate the relationship between soil contents and the plasma levels of selenium, chromium and manganese in healthy adult Nigerians. The study also determines the effect of age and sex of the subjects on their selenium, chromium and manganese plasma levels. Few studies have been reported on the plasma levels of selenium, chromium and manganese in Nigeria, in spite of the accumulating evidence that these trace elements are of immense benefit in the health and wellbeing of man.

\section{MATERIALS AND METHODS}

\section{Sample collection}

Soil samples were collected from Uyo, Calabar, Oron, Ikom and Ikot Okpora in Cross River State and Akwa Ibom State (Figures 1, 2 and 3 ), which were the five different experimental location for the determination of selenium, chromium and manganese. Blood was drawn in the morning into heparinised disposable plastic syringes from 160 healthy adult Nigerians from rural and urban communities of Akwa Ibom and Cross River States in the South-south Zone of Nigeria. Plasma was immediately separated out by centrifuging the blood samples at $3000 \mathrm{rpm}$ for $10 \mathrm{~min}$. The samples were stored at $-20^{\circ} \mathrm{C}$ until required for analysis. The population was made up of 24 elderly subjects ( 16 men and eight women) aged between 51 to 90 years and 126 younger adults made up of 42 men and 54 women aged 18 to 50 years. All the subjects ate ordinary foods and diets purchased from local restaurants and markets in the five experiment areas.

\section{Trace metals analysis}

Trace metals analysis was done using a Unicam 939/959 atomic absorption spectrophotometer. The assessment of the trace metals nutritional status on the basis of plasma concentration must be used with several important caveats. Assay methods and reference standards are at an early stage. Taking all the studies available into account, it is possible to state with some confidence that at blood concentration of approximately $1.0 \mathrm{U} \mathrm{mol} / \mathrm{l}$, there is good correlation between plasma selenium concentration and the activity of Glutathione Peroxidase (GPx) in erythrocytes and therefore plasma selenium concentration may be taken as good index of nutritional status with respect to selenium.

\section{Statistical analysis}

The statistical analysis of the data was done with the statistical package for the social science (SPSS) software. The values obtained from this study were expressed as mean and standard deviation when compared using t-test. Pearson correlation was used to determine relationships between variables.

\section{RESULTS}

The mean values \pm SD for selenium, chromium and manganese concentrations in soil samples are shown in Table 1. The mean \pm SD soil selenium concentration was $2.86 \pm 3.97 \mathrm{mg} / \mathrm{kg}$ and values ranged from 0.002 to 8.08 $\mathrm{mg} / \mathrm{kg}$. The mean soil chromium concentration was 15.93 $\pm 3.35 \mathrm{mg} / \mathrm{kg}$ and values ranged from 6.86 to 26.61 $\mathrm{mg} / \mathrm{kg}$. The mean soil manganese concentration was $90.33 \pm 42.65 \mathrm{mg} / \mathrm{kg}$ and values ranged from 23.95 to $130.00 \mathrm{mg} / \mathrm{kg}$. The concentration of manganese was the highest and selenium concentration was the lowest in the locations. The plasma selenium, chromium and manganese of the subjects categorized by age and sex are shown in Table 2 . The mean \pm SD plasma selenium concentration for 59 healthy subjects, females $(n=29)$ and males $(n=30)$ was $0.004 \pm 0.006 \mathrm{mg} / \mathrm{l}$. Selenium was not detected in other subjects. Statistically, there was no significant difference ( $p>0.05$ ) between values for males and females as determined by t-test. Since there was no significant effect of sex on selenium values obtained, data from males and females were pooled. No significant correlation between age and plasma selenium levels was obtained $(p>0.05)$. However, there was negative correlation for plasma selenium concentration in males aged 18 to 30 years $(r=-0.0757, p=0.05)$. There was precipitous fall in plasma selenium concentration from ages 25 to 35 years (Figure 4). There was further 


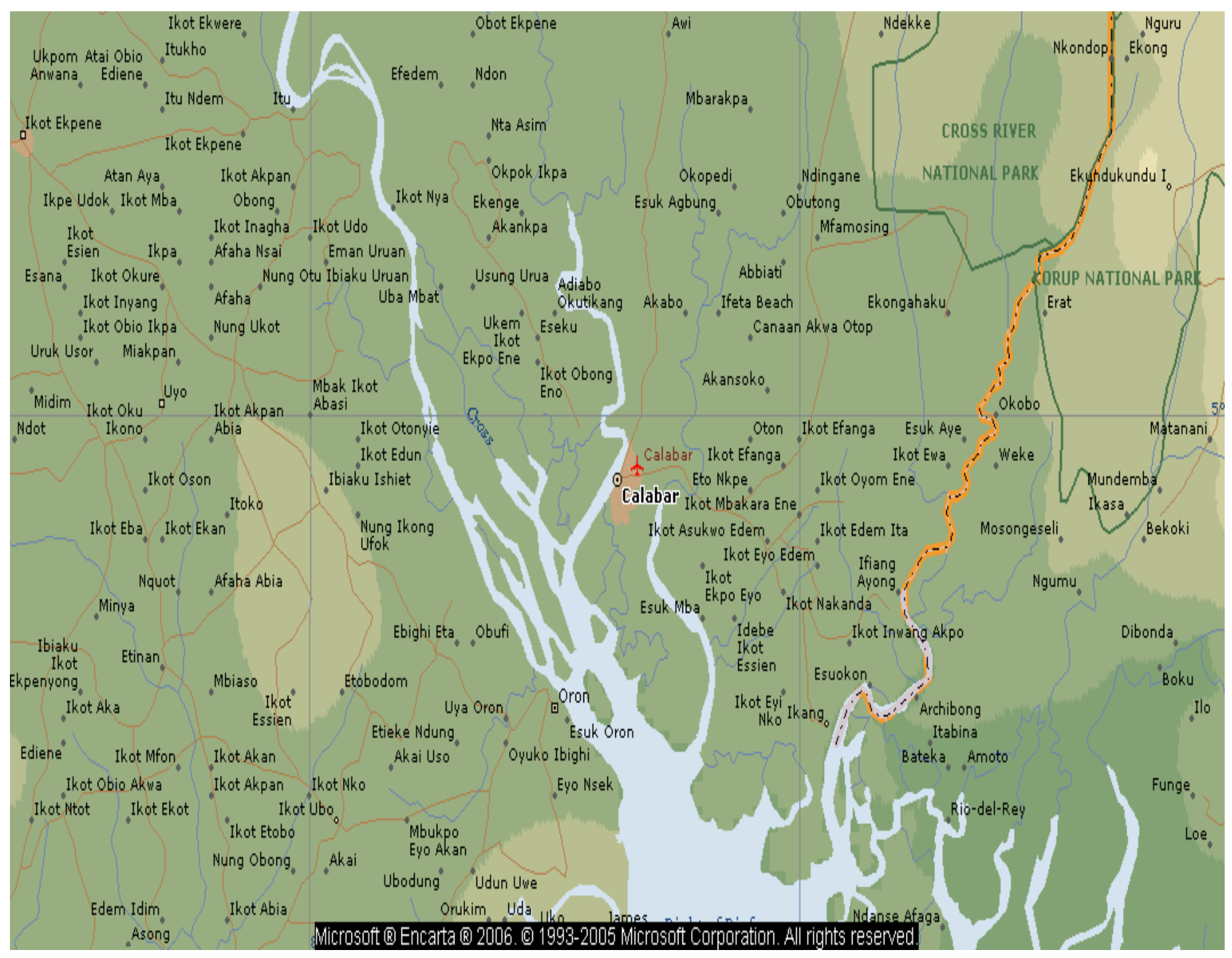

Figure 1. Map showing Uyo, Calabar and Oron, Nigeria.

decline until age 65. Plasma selenium concentration rose very slightly from age 75 to 85 years. There was no significant difference between selenium values in plasma and soil as determined by t-test.

The mean \pm SD plasma chromium concentration was $0.111 \pm 0.03 \mathrm{mg} / \mathrm{l}$ for 73 healthy subjects. No chromium was detected in the other subjects. The mean plasma chromium concentration for females $(n=38)$ was $0.108 \pm$ $0.03 \mathrm{mg} / \mathrm{l}$ and $0.114 \pm 0.32 \mathrm{mg} / \mathrm{l}$ for males $(\mathrm{n}=35)$. There was no significant difference between the values for males and females. No statistically significant correlation between age and plasma chromium levels was observed ( $p>0.05$ ). Plasma chromium levels tended to be stable $(0.126 \mathrm{mg} / \mathrm{l})$ between ages 25 and 45 . There was a sharp decline between ages 45 and 55 from 0.126 to $0.096 \mathrm{mg} / \mathrm{l}$ (Figure 4). Plasma chromium levels stabilized again between ages 55 and $65(0.063 \mathrm{mg} / \mathrm{l})$. It rose sharply thereafter and tended to be stable between the ages of 75 and 85 . There were no significant correlation between chromium values in plasma and soil. The mean plasma manganese concentration was $0.028 \pm 0.02 \mathrm{mg} / \mathrm{l}$ for 89 adults. No manganese was detected in other healthy subjects. The mean \pm SD plasma manganese concentration for females $(n=50)$ was $0.023 \pm 0.01 \mathrm{mg} / \mathrm{l}$ and $0.035 \pm 0.04 \mathrm{mg} / \mathrm{l}$ for males $(\mathrm{n}=39)$. Manganese was not detected in the other healthy subjects.

There were no differences between manganese values in plasma and soil as determined by t-test. Statistically, there was no significant correlation between age and plasma manganese levels ( $p>0.05)$. However, there was a highly significant correlation $(r=1.000, p=0.01)$ for plasma manganese concentration in females aged 51 and 60 years. There was a sharp decline from age 25 $(0.041 \mathrm{mg} / \mathrm{l})$ to 45 years $(0.018 \mathrm{mg} / \mathrm{l})$. It rose thereafter 


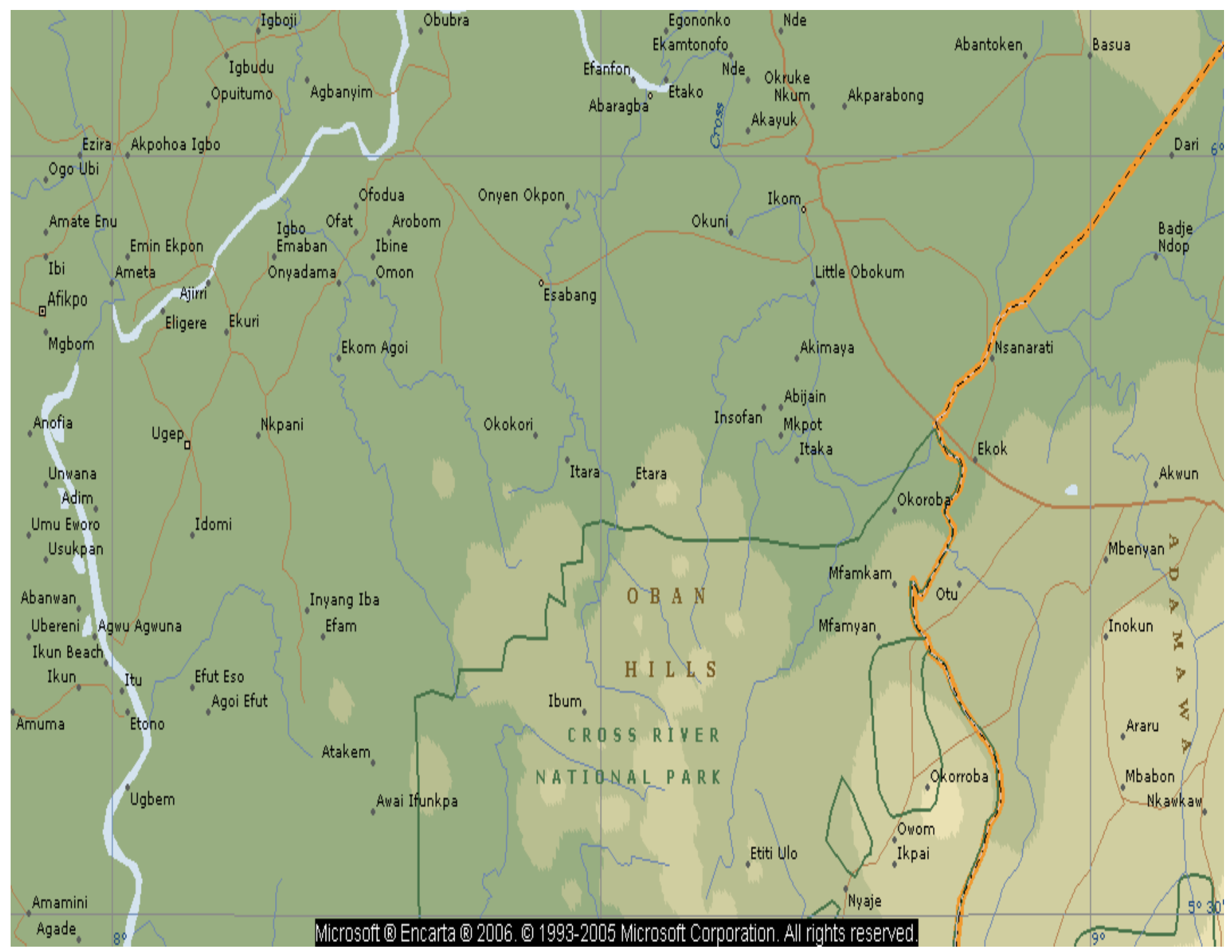

Figure 2. Map showing Ikom, Nigeria.

from age 45 to 60 years (Figure 4) and then declined sharply at age 75 years. No significant correlation was observed between plasma manganese concentration and soil manganese ( $p>0.05)$.

\section{DISCUSSION}

There is an increasing evidence for the important role which micronutrients play in the prevention of disease and promotion of overall health. These nutrients can be obtained from a diet containing a variety of foods from a variety of sources. Environmental changes and agricultural practices may be reducing nutrient concentration in the soil (Combs, 2001). The mean value of selenium $(0.004 \pm 0.006 \mathrm{mg} / \mathrm{l}$, obtained in this study for apparently healthy adults was lower than that reported for most countries for example, New Zealand (0.056 mg/l)
(Robinson et al., 1997), France $(0.087 \mathrm{mg} / \mathrm{l})$ (Coudray et al., 1997), Lagos, Nigeria, (57.05 $\pm 2.50 \mu \mathrm{g} / \mathrm{l}$ ) (Arinola and Charles - Davies, 2008), Greece (108.86 $\pm 33.88 \mu \mathrm{g} / \mathrm{l})$ (Sotiropoulos et al., 2011), UK (88.8 $\pm 19.2 \mathrm{ng} / \mathrm{g})$ (Rayman et al., 2011), England (88.5 $\pm 19.1 \mathrm{ng} / \mathrm{g}$ ) (Rayman et al., 2012) and Taiwan (106.4 $\pm 12.7 \mathrm{ng} / \mathrm{l})$ (Guo., 2013). The low content of selenium in the soils could be attributed to a decline in the availability of selenium through the food chain and in human selenium status (Daniels, 1996). Also, the low plasma selenium concentration observed in this study may reflect the intrinsically low selenium content of the soil in which the foods were grown and the low protein intake of the participants, who took mostly starchy foods. Selenium has been shown to be more available from diet of animal origin than those of plant sources (Combs, 2001). With more than $80 \%$ of the dietary selenium intake coming directly from plant sources, it is likely that availability is 


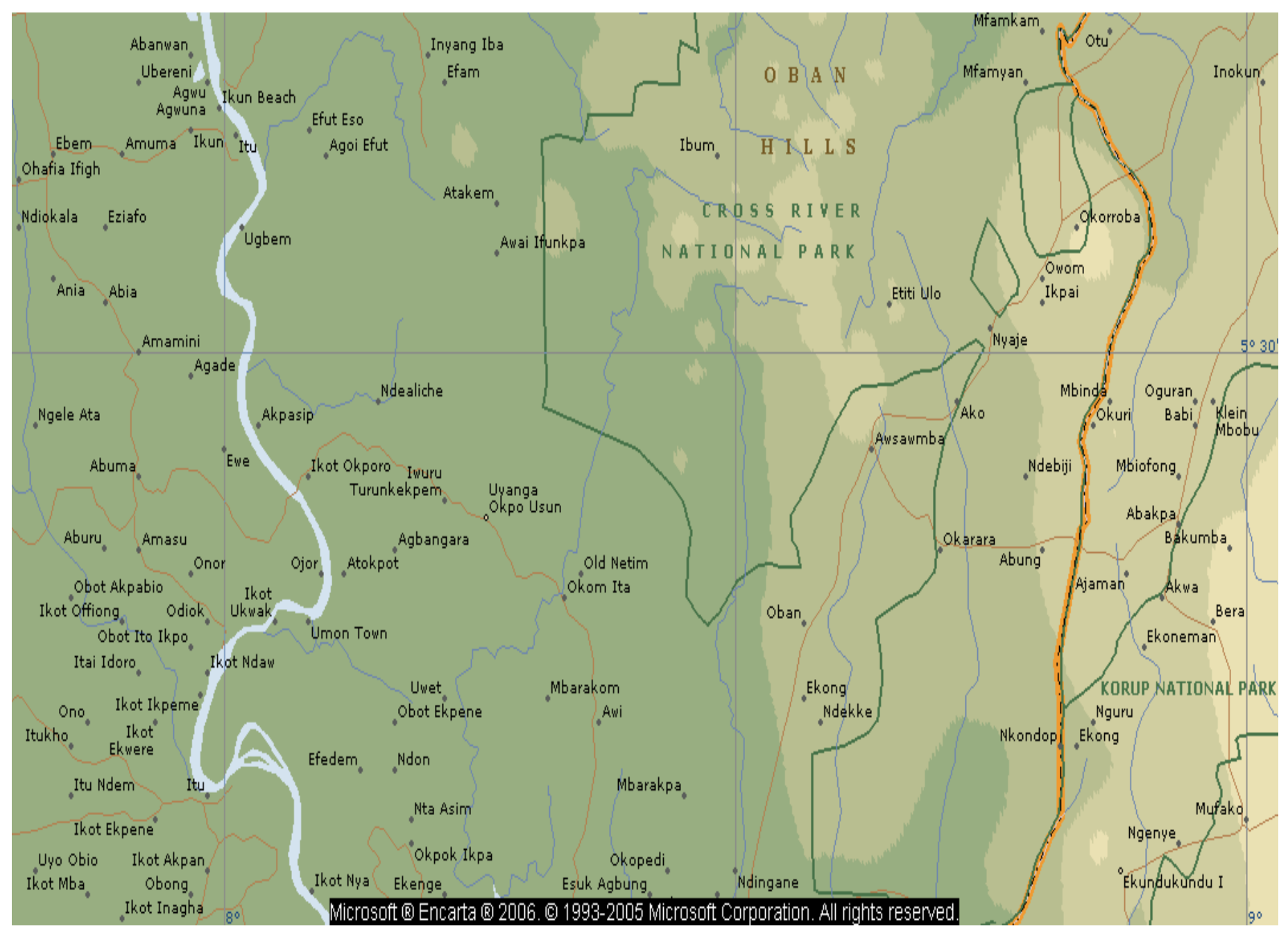

Figure 3. Map showing Ikot Ikpora, Nigeria.

Table 1. The selenium, chromium and manganese content in soil samples.

\begin{tabular}{lccc}
\hline Location & Selenium $(\mathbf{m g} / \mathbf{k g})$ & Chromium $(\mathbf{m g} / \mathbf{k g})$ & Manganese $(\mathbf{m g} / \mathbf{k g})$ \\
\hline Calabar & 0.005 & 14.73 & 23.95 \\
lkot Okpora & 0.009 & 26.61 & 102.58 \\
Ikom & 0.002 & 8.53 & 74.72 \\
Uyo & 8.08 & 6.86 & 130.00 \\
Oron & 6.22 & 12.93 & 120.4. \\
Mean $\pm S D$ & $2.86 \pm 3.97$ & $15.93 \pm 3.35$ & $90.33 \pm 42.65$ \\
\hline
\end{tabular}

low. The correlation between the local availability of selenium and the selenium status of the population might often be significant. Thus, when selenium availability is low, the local soil and plant content of the element gives an indication of the likely occurrence of diseases that may involve selenium in its etiology (Diplock, 1993).

Low levels of selenium status have been linked with senility and cognitive decline in the elderly and with Alzheimer's disease (DC Nutrition, 2003). Plasma concentration is the most commonly used indicator of selenium status. From the results, there was no significant effect of sex on the selenium values obtained. Surveys carried out by Lyons et al. (2004) showed that plasma selenium was affected by age $(p=0.008)$ and 
Table 2. The plasma selenium, chromium and manganese categorized by age and sex.

\begin{tabular}{|c|c|c|c|c|}
\hline Age group / sex & Age (years) & Selenium (mg/l) & Chromium (mg/l) & Manganese (mg/l) \\
\hline \multicolumn{5}{|l|}{ 18-90 (pooled) } \\
\hline$M+F$ & $\mathrm{n}=106$ & $\mathrm{n}=59$ & $\mathrm{n}=73$ & $\mathrm{n}=89$ \\
\hline Mean \pm SD & $22.5 \pm 3.15$ & $0.004 \pm 0.006$ & $0.111 \pm 0.031$ & $0.028 \pm 0.024$ \\
\hline \multicolumn{5}{|l|}{$18-30$} \\
\hline M & $\mathrm{n}=22$ & $\mathrm{n}=10$ & $n=13$ & $\mathrm{n}=14$ \\
\hline Mean \pm SD & $25 \pm 4.17$ & $0.003 \pm 0.002$ & $0.115 \pm 0.023$ & $0.046 \pm 0.056$ \\
\hline $\mathrm{F}$ & $\mathrm{n}=52$ & $\mathrm{n}=5$ & $\mathrm{n}=5$ & $\mathrm{n}=9$ \\
\hline Mean \pm SD & $23 \pm 2.76$ & $0.005 \pm 0.009$ & $0.109 \pm 0.032$ & $0.023 \pm 0.006$ \\
\hline \multicolumn{5}{|l|}{$31-40$} \\
\hline M & $\mathrm{n}=16$ & $\mathrm{n}=9$ & $\mathrm{n}=11$ & $\mathrm{n}=10$ \\
\hline Mean \pm SD & $36.58 \pm 2.84$ & $0.003 \pm 0.001$ & $0.113 \pm 0.047$ & $0.026 \pm 0.008$ \\
\hline $\mathrm{F}$ & $\mathrm{n}=12$ & $N=5$ & $\mathrm{n}=5$ & $\mathrm{n}=9$ \\
\hline Mean \pm SD & $35 \pm 3.09$ & $0.002 \pm 0.001$ & $0.100 \pm 0.034$ & $0.022 \pm 0.003$ \\
\hline \multicolumn{5}{|l|}{$41-50$} \\
\hline M & $\mathrm{n}=4$ & $\mathrm{n}=2$ & $\mathrm{n}=2$ & $\mathrm{n}=3$ \\
\hline Mean \pm SD & $46.50 \pm 0.71$ & 0.002 & $0.125 \pm 0$ & $0.019 \pm 0.006$ \\
\hline $\mathrm{F}$ & $\mathrm{n}=11$ & $n=3$ & $\mathrm{n}=4$ & $\mathrm{n}=6$ \\
\hline Mean \pm SD & $46.27 \pm 3.20$ & $0.002 \pm 0$ & $0.125 \pm 0$ & $0.023 \pm 0$ \\
\hline \multicolumn{5}{|l|}{$51-60$} \\
\hline M & $\mathrm{n}=6$ & $\mathrm{n}=3$ & $\mathrm{n}=3$ & $\mathrm{n}=4$ \\
\hline Mean \pm SD & $56.5 \pm 2.74$ & $0.002 \pm 0$ & $0.104 \pm 0.036$ & $0.020 \pm 0.005$ \\
\hline $\mathrm{F}$ & $\mathrm{n}=4$ & $\mathrm{n}=1$ & $\mathrm{n}=1$ & $\mathrm{n}=3$ \\
\hline Mean \pm SD & $55.7 \pm 2.87$ & $0.004 \pm 0$ & $0.125 \pm 0$ & $0.031 \pm 0.014$ \\
\hline \multicolumn{5}{|l|}{$61-70$} \\
\hline M & $\mathrm{n}=5$ & $\mathrm{n}=1$ & $\mathrm{n}=3$ & $\mathrm{n}=3$ \\
\hline Mean \pm SD & $63 \pm 0.00$ & $0.004 \pm 0$ & $0.104 \pm 0.009$ & $0.036 \pm 0.026$ \\
\hline $\mathrm{F}$ & $\mathrm{n}=4$ & $n=1$ & $\mathrm{n}=1$ & $\mathrm{n}=2$ \\
\hline Mean \pm SD & $66 \pm 2.00$ & $0.002 \pm 0$ & $0.063 \pm 0$ & $0.035 \pm 0.026$ \\
\hline \multicolumn{5}{|l|}{$71-80$} \\
\hline M & $\mathrm{n}=4$ & $\mathrm{n}=4$ & $\mathrm{n}=2$ & $\mathrm{n}=4$ \\
\hline Mean \pm SD & $75.5 \pm 3.3$ & $0.003 \pm 0.0012$ & $0.125 \pm 0$ & $0.035 \pm 0.014$ \\
\hline $\mathrm{F}$ & $\mathrm{n}=1$ & $\mathrm{n}=1$ & $\mathrm{n}=1$ & $\mathrm{n}=1$ \\
\hline Mean \pm SD & 85 & 0.004 & 0.125 & 0.047 \\
\hline
\end{tabular}

$\mathrm{M}$, Male; f, female.

sex $(p=0.01)$. Plasma concentration of selenium from this study showed that it increased with age. Women had lower selenium levels than men (Kaifa et al., 2003). In the study by Akbaraly et al. (2010), the selenium level was $1.08 \pm 0.21 \mu \mathrm{mol} / \mathrm{l}$ in men and $1.10 \pm 0.20 \mu \mathrm{mol} / \mathrm{l}$ in women. Most studies have found little relationship between sex and blood selenium concentration in adults (Bates et al., 2002) unless in late term pregnancy or those who are lactating (Reyes et al., 2000). But Arinola and Charles - Davies (2008) in a study on females with breast cancer had selenium value of $52.25 \pm 2.17 \mu \mathrm{g} / \mathrm{l}$. The mean value of chromium $(0.111 \pm 0.031 \mathrm{mg} / \mathrm{l})$ obtained in this study for 73 apparently healthy subjects was higher than that reported by Arinola and Akinbinu (2006) with $0.047 \pm 0.019 \mathrm{mg} / \mathrm{l}$ and Arinola and Charles Davies (2008) with $52.25 \pm 2.17 \mu \mathrm{g} / \mathrm{l}$ mean plasma 


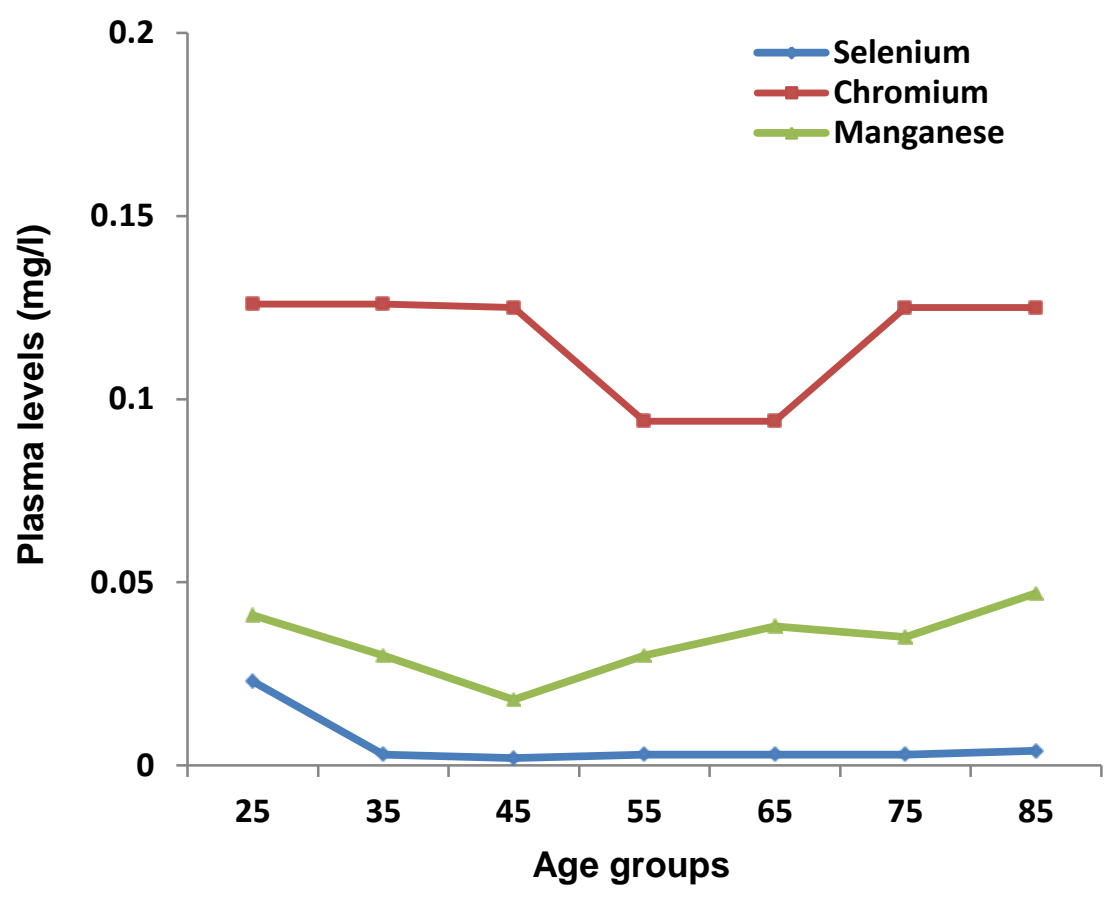

Figure 4. Plasma distribution with age of healthy adult Nigerians.

chromium concentrations. The mean value of chromium in plasma in healthy adults in studies by Chernecky and Berger (1997) was between 0.18 and $0.47 \mathrm{mg} / \mathrm{l}$, Van Buynder (2010) was $5.17 \pm 1.53 \mathrm{nmol} / \mathrm{l}$ and Newton et al. (2012) was $53.8 \mathrm{nmol} / \mathrm{l}$.

Diet is the main source of chromium in humans; it is found in minute amounts in foods. Processed meats, whole grain products, ready-to-eat bran cereals, broccoli and spices are relatively high in chromium. But only 1 to $2 \%$ of the chromium delivered by the diet is absorbed. From the study, there was no significant effect of sex on the plasma values obtained. Plasma chromium level tended to be stable between the ages of 25 to 45 years and declined sharply thereafter. Plasma chromium level stabilized again between the ages of 55 to 65 and 75 to 85 years and rose sharply thereafter. This agreed with the study by Nourmohammadi et al. (2005), who reported that chromium levels stabilize at certain ages and then decline. Several disease states have been associated with low levels of serum manganese (Freeland-Graves and Llanes, 1994). The mean \pm SD plasma manganese value obtained in this study for healthy adults $0.028 \pm$ $0.02 \mathrm{mg} / \mathrm{l}$ was higher than the normal range $(0.003$ to $0.010 \mathrm{mg} / \mathrm{l}$ ) (Nourmahammadi et al., 2005). This corroborates with studies by Arinola and Charles Davies, (2008) with manganese value of $65.35 \pm 2.96$ $\mu \mathrm{g} / \mathrm{l}$ in Lagos, Nigeria, Chan et al., (2009) with manganese value of $121.4 \mathrm{ng} / \mathrm{ml}$ in Boston, Omobola et al.,(2011) with manganese value of $63.20 \pm 3,9 \mu \mathrm{g} / \mathrm{dl}$ in Abeokuta, South-west Nigeria, Roos et al.,(2012) with manganese value of $0.78 \mu \mathrm{g} / \mathrm{l}$ and Yuyan et al. (2012) with manganese value of $8.2 \mu \mathrm{g} / \mathrm{l}$ in China. The high plasma manganese value obtained in this study may reflect the high soil content in the region.

Values obtained in this study show that there was no significant correlation between age and plasma manganese. However, there was a significant correlation for plasma concentration in females aged 51 to 60 years. There was no significant effect of sex on plasma values although females had lower plasma manganese levels than the males.

\section{Conclusion}

Soil contents of micronutrients have significant impact on their plasma concentrations. Plasma levels of chromium and manganese seem to be adequate in healthy adult Nigerians. The plasma levels of selenium of healthy adults Nigerians appeared to be low. Supplementation may therefore be of benefit. Statistically, age and sex appear to have no significant effects on the plasma levels of selenium, chromium and manganese. Interactions between selenium, chromium and manganese in soil and subsequently in foods and diet showed the influence of the plasma levels of some of these trace nutrients in varying degrees.

\section{REFERENCES}

Akbaraly TN, Arnaud J, Rayman MP, Hininger-Favier I, Roussel AM, Berr C, Fontbonne A (2010). Plasma selenium and risk of 
dysglycemia in an elderly French population: results from the prospective epidemiology of vascular ageing study. Nutr. Metab. 7:21.

Arinola OG, Akinbinu MO (2006). The levels of antioxidants and some trace metals in Nigerians that are occupationally exposed to chemicals. Official Publication of Indian Association of Occupational Health 10(2):65-68.

Arinola OG, Charles-Davies (2008). Micronutrient levels in the plasma of Nigerian females with breast cancer. Afr. J. Biotechnol. 7(11):1620.

Bates CJ, Thane CW, Prentice A, Delves HT (2002). Selenium status and its correlates in a British national diet and nutrition survey: people ages 65 years and over. J. Trace Elem. Med. Biol. 16:1-8

Chan JM, Oh WK, Xie W, Regan MM, Stampfer MJ, King IB, Abe M, Kantoff PW (2009). Plasma selenium, manganese superoxide dismutase,and intermediate-or high-risk prostate cancer. J. Clin. Oncol. 27(22):3577-3583.

Chernecky CC, Berger BJ (1997). Laboratory tests and diagnostic procedures $2^{\text {nd }}$ ed. Philadelphia, Saunders. pp. 367-368.

Combs GF (2001). Selenium in global food systems. Br. J. Nutr. 85(5):517-547.

Combs GF, Clark LC, Turnbull BW (1997). Reduction of cancer risk with an oral supplement of selenium. Biomed. Environ. Sci. 10:227-234.

Coudray C, Roussel AM, Mainard F, Arnaud J, Favier A (1997). Lipid peroxidation level and antioxidant micronutrient status in a pre-aging population; correlation with chronic disease prevalence in a French epidemiological study (Nantes, France) J. Am. Coll. Nutr. 16:584-591.

Daniels LA (1996). Selenium metabolism and bioavailability. Biol. Trace Elem. Res. 54:185-199

DC Nutrition (2003). Selenium - general discussion. Selenium deficiency diseases pl file: //A:/DC Nutrition (selenium).htm .

Diplock AT (1993). Indexes of selenium states in human populations. Am. J. Clin. Nutr. Suppl. 57:256S-258S

Eckhardt CL (2006). Micronutrient malnutrition, obesity and chronic disease in countries undergoing the nutrition transition: potential links and program/policy implication: International Food Policy Research Institute.

Fairweather - Tait SJ (1997). Minerals and trace elements - summary. Europ. J. Clin. Nutr. 51: supplement 1, S3.

Freeland - Graves J, Llanes C (1994). Models to study manganese deficiency in Klinmics - Tavantzis DL, ed. Manganese in health and disease. Boca Raton CRC Press, Inc. pp. 59-86.

Guo CH, Chan PC, Hsu GS, Wang CL (2013). Zinc supplementation alters plasma aluminium and selenium status of patients under going dialysis: a pilot study. Nutrients 5:1456-1470.

Kafai MR, Gangi V (2003). Sex, age, geographical location, smoking and alcohol consumption influence serum selenium concentration in the USA, third health and nutrition survey, 1993 - 1994. J. Trace Elem. Med. Biol. 17:13-18.

Keen CL, Zindenberg - Cherr S (1996). Manganese. In: Ziegler E.E., and Filer L. J. (eds). Present Knowledge in Nutrition. 7th ed. Washington DC ILSI Press. pp. 334-343.

Lyons GH, Judson GT, Stangoulis JCR, Palmer LT, Jones JA, Graham RD (2004). Trends in selenium status of South Australians. Med. J. Aust. 180(8): 383-386.
Newton AW, Ranganath L, Armstrong C, Peter V, Roberts NB (2012). Differential distribution of cobalt, chromium, and nickel between whole blood, plasma and urine in patients after metal-on-metal (MOM) hip arthroplasty. J. Orthop. Res. 30(10):1640-1646.

Nourmohammadi I, Kocheki-Shalmani, Shaabani M, Gohari L, Nazari H (2005). Zinc, copper, mangnese and magnesium levels in serum and hair of insulin-dependent diabetics: internet available from http://www.ams.ac.ir /AIM0033/nour 00333.html.

Omobola A. Ogundahunsi, Olaniyi O. Duduyemi and Oluwatosin $O$. Soyinka (2011). Effect of antipsychotic drugs on the levels of selected trace elements in schizophrenia: African Scientist 12(2):7782.

Paul Van Buynder (2010). Evaluation of chromium in blood. A report prepared by ChemRisk Canada, a division of ChemRisk LLP, Guelph, Ontario N1H7L6.

Rayman MP, Stranges S, Griffin BA, Pastor - Barriuso R, Guallar E (2011). Effect of supplementation with high - selenium yeast on plasma lipids: a randomized trial. Ann. Intern. Med. 154(10): 656 - w 240. ISSN 0003 - 4819.

Rayman, M. P, Blundell - Pound, G, Pastor - Barriuso, R, Guallar, E, Steinbrenner, $\mathrm{H}$ and Stranges, $\mathrm{S}$ (2012). A randomized trial of selemium supplementation and risk of type - 2 diabetes as assessed by plasma adiponectin. PLOS ONE (7) 9: e 45269.

Reyes H, Baez ME, Gonzalez C (2002). Selenium, zinc, copper plasma levels in intrahepatic cholestatis of pregnancy, in normal pregnancies and in healthy individuals in Chile. J. Hepatol. 32:542-549

Robinson MF, Thomson CD, Jenkins P (1997). Long term supplementation with selenate and selenomethionine urinary excretion by New Zealand women. Br. J. Nutr. 77(4): 551-563.

Roos PM, Lierhagen S, Flaten TP, Syversen T, Vesterberg O, Nordberg $M$ (2012): Mangenese in cerebrospinal fluid and blood plasma of patients with amytrophic sclerosis. Experimental Biology and Medicine: 237:803-810.

Sotiropoulos A, Papadodina SA, Papazafiropoulou AK, Ioannidis A, Kokkinari A, Apostolou O, Spiliopoulou CA, Athanaselis S (2011). Serum selenium levels do not differ in type 2 diabetic subjects with and without coronary artery disease. BMC Res. Notes 4:270.

Tuormaa TE (1995). The role of chromium, selenium and copper in human and animal metabolism. J. Orthomol. Med. 10(384):149-164.

Vincent JB (2000). Elucidation of a biological role for chromium at a molecular level. Acc. Chem. Res. 33(7):503 - 510.

Yuyan, Li, Junqing Wu, Weijin Zhou and Ersheng Gao (2012): Effects of managanese on routine semen quality parameters: results from a population - based study in China: BMC Public Health12:919. 